\title{
Microconchids (Tentaculita) from the Middle Jurassic of Poland
}

\author{
MICHAŁ ZATOŃ \& PAUL D. TAYLOR
}

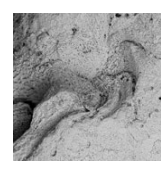

\begin{abstract}
Spirorbid-like worm tubes, identified as microconchids (Tentaculita) on the basis of morphological and microstructural features, were common and occupied a wide array of environments during the Palaeozoic and Triassic. In the Jurassic, however, microconchids were very rare, represented by only one genus, Punctaconchus Vinn \& Taylor, 2007, and confined to normal marine settings. In the present paper, the microconchid Punctaconchus ampliporus Vinn \& Taylor, 2007, characterised by large punctae penetrating the exterior of the tubes, is described from the Middle Jurassic of the Polish Jura for the first time. Individuals were found encrusting Lower Bathonian oncoliths. Their low abundance and diversity on the oncoliths may reflect poor competitive ability for substrate space leading up to the final extinction of the group in the late Bathonian. Key words: Microconchida, spirorbids, Jurassic, oncoliths, Poland.
\end{abstract}

ZAtó́, M. \& TAYLOR, P.D. 2009. Microconchids (Tentaculita) from the Middle Jurassic of Poland. Bulletin of Geosciences 84(4), 653-660 (3 figures). Czech Geological Survey, Prague. ISSN 1214-1119. Manuscript received October 30, 2009; accepted in revised form November 10, 2009; published online December 18, 2009; issued December 31,2009 .

Michat Zatoń (corresponding author), University of Silesia, Faculty of Earth Sciences, Będzińska 60, 41-200 Sosnowiec, Poland; mzaton@wnoz.us.edu.pl • Paul D. Taylor, Natural History Museum, Department of Palaeontology, Cromwell Road, London SW7 5BD, United Kingdom; p.taylor@nhm.ac.uk

Microconchids are small, spirally-coiled, encrusting worm tubes that range from Ordovician to Middle Jurassic (see Vinn 2006, Taylor \& Vinn 2006, Vinn \& Taylor 2007). For decades microconchids were misidentified as the wellknown polychaete Spirorbis (see Taylor \& Vinn 2006) because of their strong morphological and ecological convergence with that group. However, on the basis of early tube ontogeny and microstructure, pre-Cretaceous Spirorbislike fossils have been reclassified as microconchids belonging to the Class Tentaculita Bouček, 1964 (see Weedon 1991, 1994; Dreesen \& Jux 1995; Taylor \& Vinn 2006). Microconchids differ from true Spirorbis, as well as related serpulids such as Spirorbula, in having lamellar, pseudopunctate or punctate tubes and a bulb-like tube origin contrasting with the open origin in Spirorbis (Weedon 1991, Vinn 2006, Taylor \& Vinn 2006, Vinn \& Taylor 2007). On the basis of such structural comparative studies (see Taylor \& Vinn 2006), it is apparent that: (1) supposed Palaeozoic examples of Spirorbis are microconchids; and (2) microconchids persisted into the mid-Mesozoic before being replaced by spirorbid annelids, possibly as late as the $\mathrm{Ce}$ nomanian Stage of the Cretaceous (Vinn 2006, Vinn \& Taylor 2007).

Whereas Palaeozoic and Triassic microconchids are common (see Dreesen \& Jux 1995, Vinn \& Taylor 2007), those from the Jurassic are rare, being currently described only from England and France (see Vinn \& Taylor 2007). Thus, any new data about Jurassic microconchids is important for a better understanding of their diversity, ecology and palaeobiogeography during the time of their decline. Although briefly mentioned as occurring in the Upper Bathonian-Lower Callovian Balin Oolite of southern Poland by Taylor (2009, p. 19), here for the first time we describe microconchids from the Middle Jurassic (Bathonian) of the Polish Jura.

\section{Geological setting}

During the Middle Jurassic, the Polish Basin was an eastern part of the Mid-European Epicontinental Basin. To the north, east and south-west, it was bordered by the Fennoscandian, Belorussian, Ukrainian and Bohemian land masses, respectively (see Dadlez 1989, Ziegler 1990). To the south, the pre-Carpathian land bordered the epicontinental Polish Basin from the Tethys Ocean. During the Bathonian, the basin progressively expanded, attaining its maximum extent in late Bathonian times (Matyja \& Wierzbowski 1998, 2006). During the Bajocian and Bathonian, the Polish Basin was largely characterised by siliciclastic sedimentation. In the Polish Jura area, situated in south and south-central Poland, the Bajocian and 


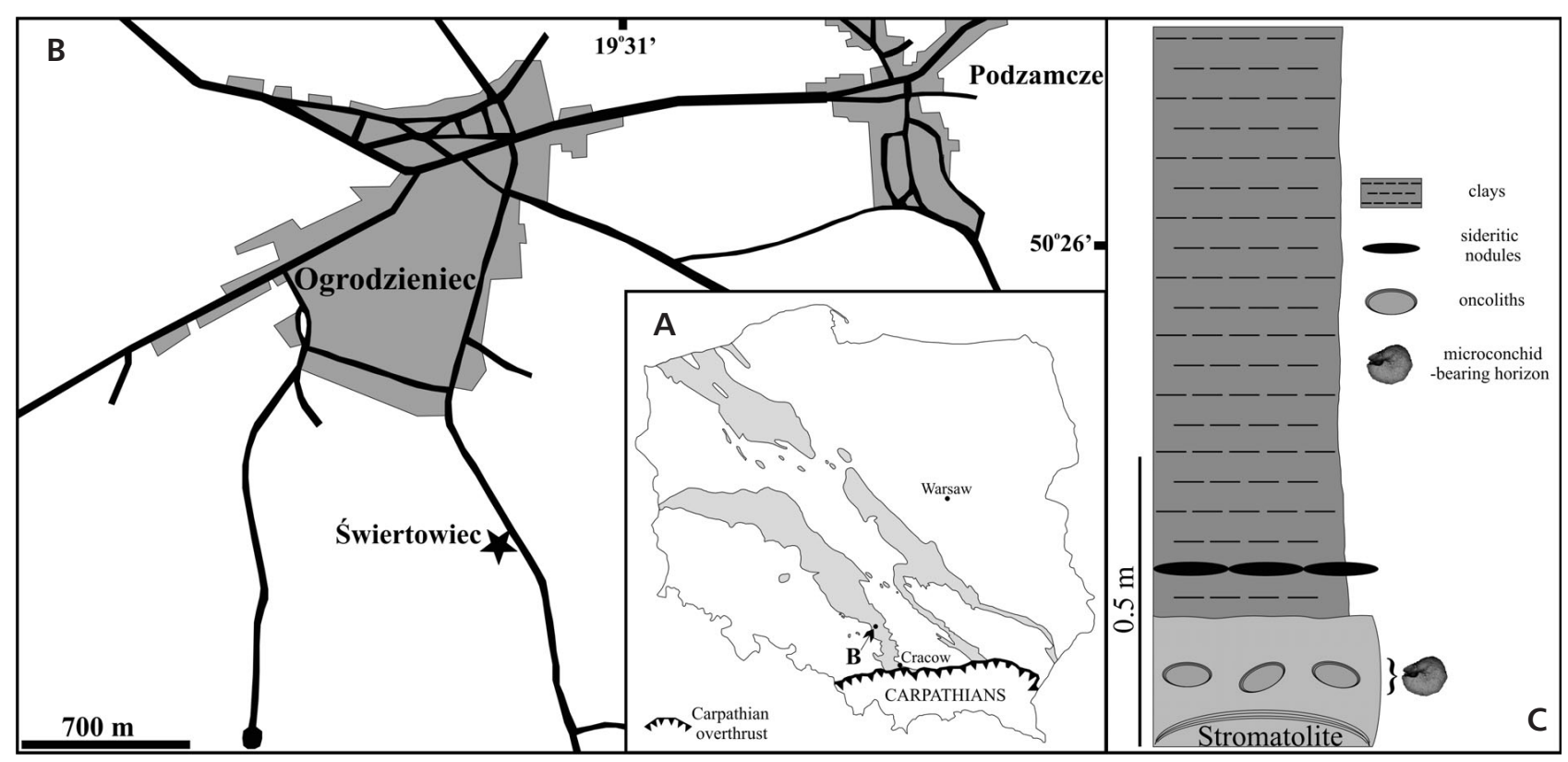

Figure 1. A - map of Poland with Jurassic deposits indicated (shaded areas) after removal of the Cenozoic cover. B - locality sketch-map with the sampled site indicated (asterisk). C - schematic section of the microconchid-bearing Bathonian deposits.

Bathonian is represented mainly by unconsolidated claystones and mudstones, dark-grey to black in colour, characteristically intercalated with single to horizon-forming carbonate nodules and massive siderite beds (e.g., Kopik 1998, Majewski 2000, Matyja \& Wierzbowski 2000, Marynowski et al. 2007, Zatoń et al. 2009). This siliciclastic sequence is referred to as the Ore-Bearing Częstochowa Clay Formation (see e.g., Dayczak-Calikowska et al. 1997, Kopik 1998, Matyja \& Wierzbowski 2000), and the deposits themselves, due to their softness, are simply called clays. Stratigraphically, the currently exposed ore-bearing clays range from Upper Bajocian (Parkinsoni Zone) to Upper Bathonian (Discus Zone), and generally are overlain by condensed Callovian sandstones and marls (see Kopik 1998, Poulsen 1998, Matyja \& Wierzbowski 2000, Barski et al. 2004, Matyja et al. 2006a-c, Zatoń et al. 2009).

The specimens studied here come from a locality at Ogrodzieniec-Świertowiec (now simply named Ogrodzieniec) in the southern part of the Polish Jura (Fig. 1A, B). According to Różycki (1953), the Ogrodzieniec locality occurs within the so-called southern sedimentary region that, in contrast to the northern sedimentary region, is characterised by thinner deposits, commonly condensed and containing hiatuses. Palaeogeographically, this region is thought to represent the marginal marine facies zone.

In Ogrodzieniec, the studied section (Fig. 1C) is not well exposed, being covered by vegetation and slumped clays. However, it starts with a concretionary bed (ca $20 \mathrm{~cm}$ thick), overlain by dark-grey clays with irregular siderite concretions near their base. The most important is the concretionary bed that contains large (up to $20 \mathrm{~cm}$ along their longest axis), disc-shaped oncoliths. These occur as one distinct horizon with the oncoliths lying horizontally, obliquely or even vertically with respect to bedding. Just below this horizon is a thick stromatolite-like crust on a massive concretionary horizon.

The oncoliths are composed of an inner core and an outer laminated crust. The core is usually formed by pebble- to cobble-sized carbonate concretions, but ammonite shells have also been noted. Some cores were resident on the sea-floor for significant periods, as shown by bivalve borings belonging to the ichnogenus Gastrochaenolites. Oncolith crusts are laminated, sometimes with the laminae stained by limonite. A characteristic of the crusts is that they are heavily encrusted by a diverse assemblage of sclerobionts, including the microconchids described in the present paper.

The ammonites retrieved from the bed, such as Parkinsonia (Oraniceras) gyrumbilica (Quenstedt, 1887), indicate that the encrusted oncoliths are not younger than the Lower Bathonian Macrescens Subzone of the Zigzag Zone.

\section{Material and methods}

During examination of 40 large and well-preserved oncoliths, as well as a few smaller fragments, 16 specimens of microconchids were found. They were removed from their substrates using a needle, briefly cleaned in an ultrasonic cleaner, and inspected using a binocular microscope. Fourteen specimens with well-preserved tubes were studied uncoated using a Philips XL30 Environmental Scanning 

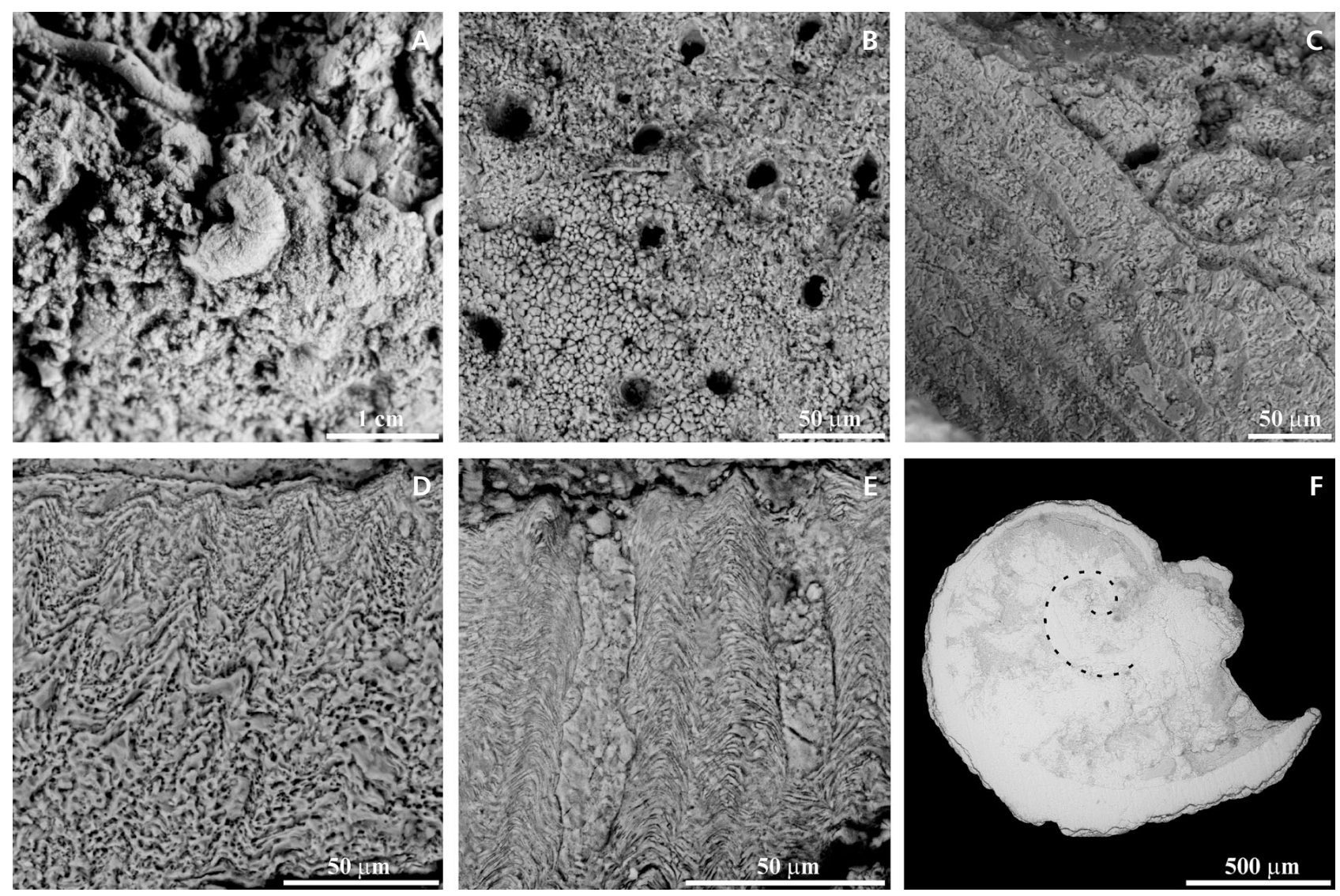

Figure 2. Morphological and microstructural features of microconchids from the Lower Bathonian of Ogrodzieniec, Polish Jura. • A - microconchid tube attached to an oncolith. $\bullet \mathrm{B}$ - large punctae visible on the external surface of a tube. $\bullet \mathrm{C}$ - rippled ornament on the tube interior. $\bullet \mathrm{D}-$ microlamellar, wavy tube microstructure. $\bullet \mathrm{E}$ - tube microstructure showing lamellae deflected outwards around the punctae filled with cement. $\bullet \mathrm{F}-$ polished specimen showing the bulb-like, closed tube origin.

Microscope (ESEM), enabling imaging in back-scattered electron mode. Two specimens were embedded in epoxy resin and gently polished and etched with weak $\mathrm{HCl}$ for a few seconds to make the microstructure of the tube walls visible under the ESEM. The state of preservation of the investigated microconchids varies, from well-preserved tubes with external characteristics visible, to badly preserved tubes having moderately to heavily worn surfaces, including exfoliation of skeletal layers, and pores completely filled by calcite cement.

All specimens are housed in the Department of Stratigraphy \& Palaeontology, Faculty of Earth Sciences at Sosnowiec, Poland, under the registration number GIUS 8.

\section{Morphological and microstructural evidence for microconchid affinity}

Although the tightly coiled tubes of the specimens investigated (Fig. 2A) are clearly similar to spirorbid polychaetes, several morphological and microstructural features distinguish the Polish microconchids from spirorbids. These fea- tures are: (1) punctae visible on the external surfaces of tubes (Fig. 2B); (2) rippled ornament on the tube interior surfaces (Fig. 2C); (3) microlamellar, wavy tube microstructure with lamellae deflected outwards around the punctae (Fig. 2D, E); and (4) bulb-like, closed tube origins (Fig. 2F). The combination of large punctae and tube interiors covered by rippled ornament allows the specimens to be identified as Punctaconchus Vinn \& Taylor, 2007.

\section{Systematic palaeontology}

Class Tentaculita Bouček, 1964

Order Microconchida Weedon, 1991

Genus Punctaconchus Vinn \& Taylor, 2007

Type species. - Punctaconchus ampliporus Vinn \& Taylor, 2007.

Remarks. - Detailed information concerning the genus Punctaconchus was given by Vinn \& Taylor (2007) and 
will not be repeated here. However, the Polish record of Punctaconchus expands its palaeobiogeographical distribution from the Anglo-Paris to the Polish Basin during the Bathonian.

\section{Punctaconchus ampliporus Vinn \& Taylor, 2007 Figures 2A-F, 3A-L}

2007 Punctaconchus ampliporus sp. nov. - Vinn \& Taylor, p. 393, figs $1,2$.

Material. - Sixteen specimens originally encrusting oncoliths (GIUS 8-3542-3557).

Measurements. - Maximum diameter of tubes: 1.1-2.2 mm (mean $=1.65 \mathrm{~mm}, \mathrm{n}=11)$; diameter of aperture: $0.50-0.76 \mathrm{~mm}($ mean $=0.67 \mathrm{~mm}, \mathrm{n}=9)$; diameter of punctae: $12-21 \mu \mathrm{m}($ mean $=17 \mu \mathrm{m} ; \mathrm{n}=23)$.

Description. - Tube small, dextrally (clockwise) coiled. Outline nearly circular. Tube diameter increases rapidly and regularly. Umbilicus narrow to nearly closed, with steep slope. The tube is cemented to the substrate over its entire length, giving a flat base. No free distal portion. External surface of tube pierced by large, circular and densely spaced punctae that may slightly differ in diameter within single specimens. External ornamentation lacking in all specimens, apart from two faint parallel ridges visible in two specimens, where they occur for a very short distance ending at the aperture (Fig. 3H, K). Aperture and lumen oval in cross-section. Tube interior covered by faint, anastomosing and bifurcating rippled ridges oriented approximately perpendicular to growth direction, numbering about 4 per $100 \mu \mathrm{m}$. Tube wall microlamellar, with characteristic wavy lamellae that are deflected outwards around punctae.

Remarks. - The smooth tube exterior, large punctae and faint rippled ridges on tube interiors are characteristic features of Punctaconchus ampliporus Vinn \& Taylor, 2007, originally described from the Jurassic of England. Although the punctae may vary slightly in size both within and between specimens, they are always larger than those of the French late Bathonian species P. palmeri Vinn \& Taylor, 2007 which has punctae $5-10 \mu \mathrm{m}$ in diameter. This latter species also has perpendicular ridges on the tube exterior (see Vinn \& Taylor 2007) lacking in Polish and other material of $P$. ampliporus. The presence of faint ridges visible for a very short distance in two of the Polish specimens of $P$. ampliporus recalls the ridges seen on juvenile tubes of P. palmeri (see Vinn \& Taylor 2007). These ridges in the Polish specimens are, however, interpreted as due to intraspecific variability within the investigated population of $P$. ampliporus. The most important feature distinguishing the latter species from $P$. palmeri is the large size of the pores (O. Vinn, pers. comm. 2009). A third species of Punctaconchus, $P$. mildfordensis (Richardson, 1907) from the Bajocian of England, possesses similarly large punctae but differs from $P$. ampliporus in having strong longitudinal ridges on the tube exterior.

Stratigraphical and geographical distribution. - Middle Jurassic, Upper Aalenian-Middle/Upper Bathonian of Gloucestershire, England, and Lower Bathonian of Ogrodzieniec, Poland. A Toarcian record from Huntingdonshire, England, is questionable (see Vinn \& Taylor 2007).

\section{Palaeoecology and palaeoenvironment}

Until the Triassic, microconchids occupied a wide array of environments, from fresh- through brackish-water to normal marine to hypersaline settings (see Taylor \& Vinn 2006 and literature cited therein). However, Jurassic microconchids, all of which have been assigned to Punctaconchus, are known only from normal marine settings in England and France (Vinn \& Taylor 2007). The same is true for the Lower Bathonian microconchids described here. Apart from microconchids, the oncoliths from $\mathrm{Og}$ rodzieniec bear diverse and abundant encrusters, such as foraminifers, 'sclerosponges', solitary corals, serpulids, oysters, cyclostome bryozoans and thecideide brachiopods, pointing to a normal marine environment,. Furthermore, they are hosted in sediments containing ammonites.

The great majority of the Ogrodzieniec sclerobionts represent cryptic or coelobiontic species (e.g., Palmer \& Fürsich 1974, Wilson 1986, Palmer \& Wilson 1990, Taylor $\&$ Wilson 2003). Thus, although they can be on both the lower and upper sides of the oncoliths, periodic overturning of the growing oncoliths must have taken place. This is

Figure 3. Microconchids Punctaconchus ampliporus Vinn \& Taylor, 2007 retrieved from the Bathonian oncoliths of Ogrodzieniec, Polish Jura. - A-C - specimen GIUS 8-3552. A - entire individual; B - detail of tube surface showing large punctae; C - detail of rippled ornament on tube interior near aperture. $\bullet$ D, E - specimen GIUS 8-3553. D - entire individual; E - close-up of tube surface with punctae visible. $\bullet$ F, G - specimen GIUS 8-3555. $\mathrm{F}$ - entire individual; $\mathrm{G}$ - view of large punctae visible on the external surface of a tube. $\bullet \mathrm{H}, \mathrm{I}-$ specimen GIUS 8-3549. $\mathrm{H}-$ entire individual with ridges near the aperture visible (arrowed); I- punctae, some of which are filled with cement. $\bullet \mathrm{J}-\mathrm{L}$ - specimens GIUS 8-3547, 3546, 3551, respectively. J- specimen with exfoliated tube surface; $\mathrm{K}$ - tube with ridges near the aperture (arrowed). 

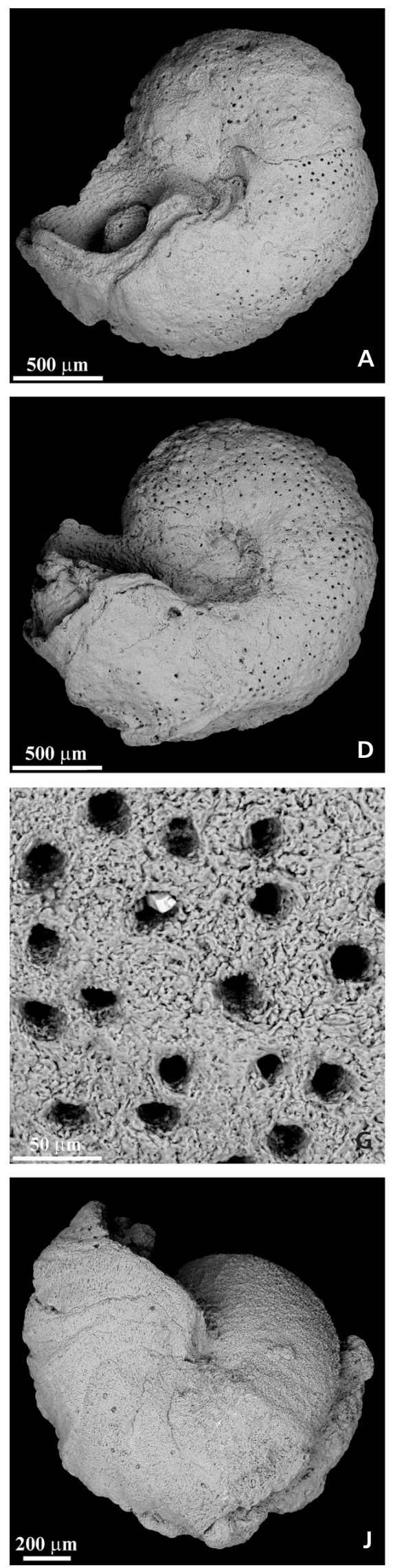
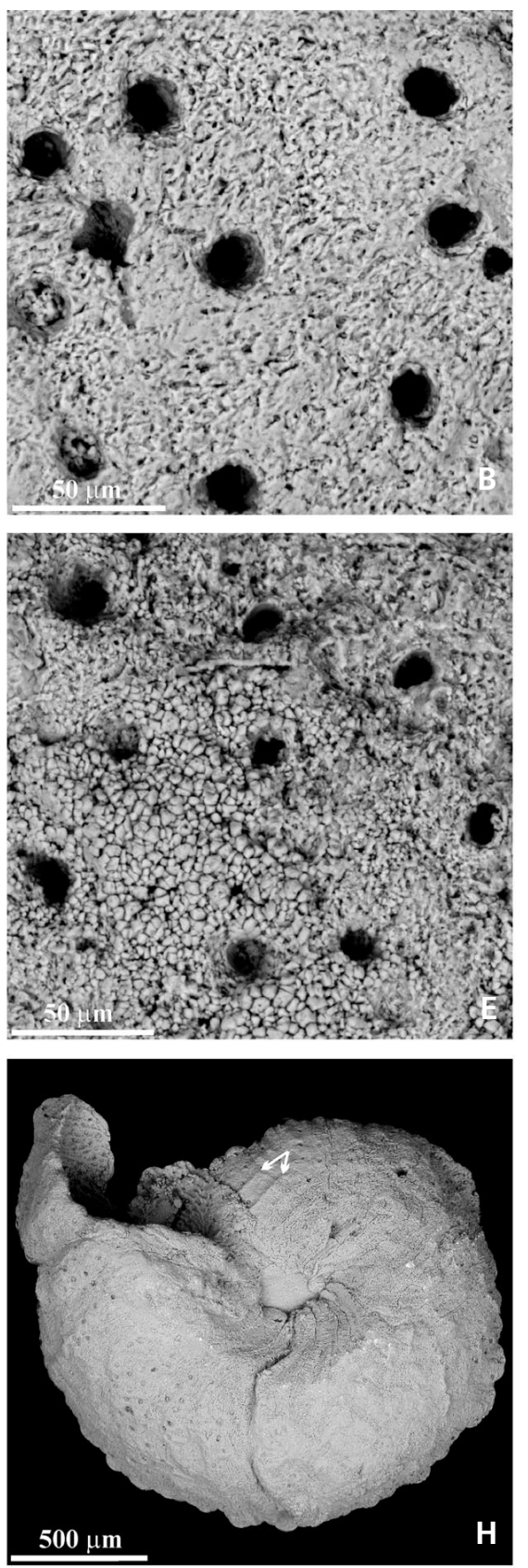

$500 \mu \mathrm{m}$
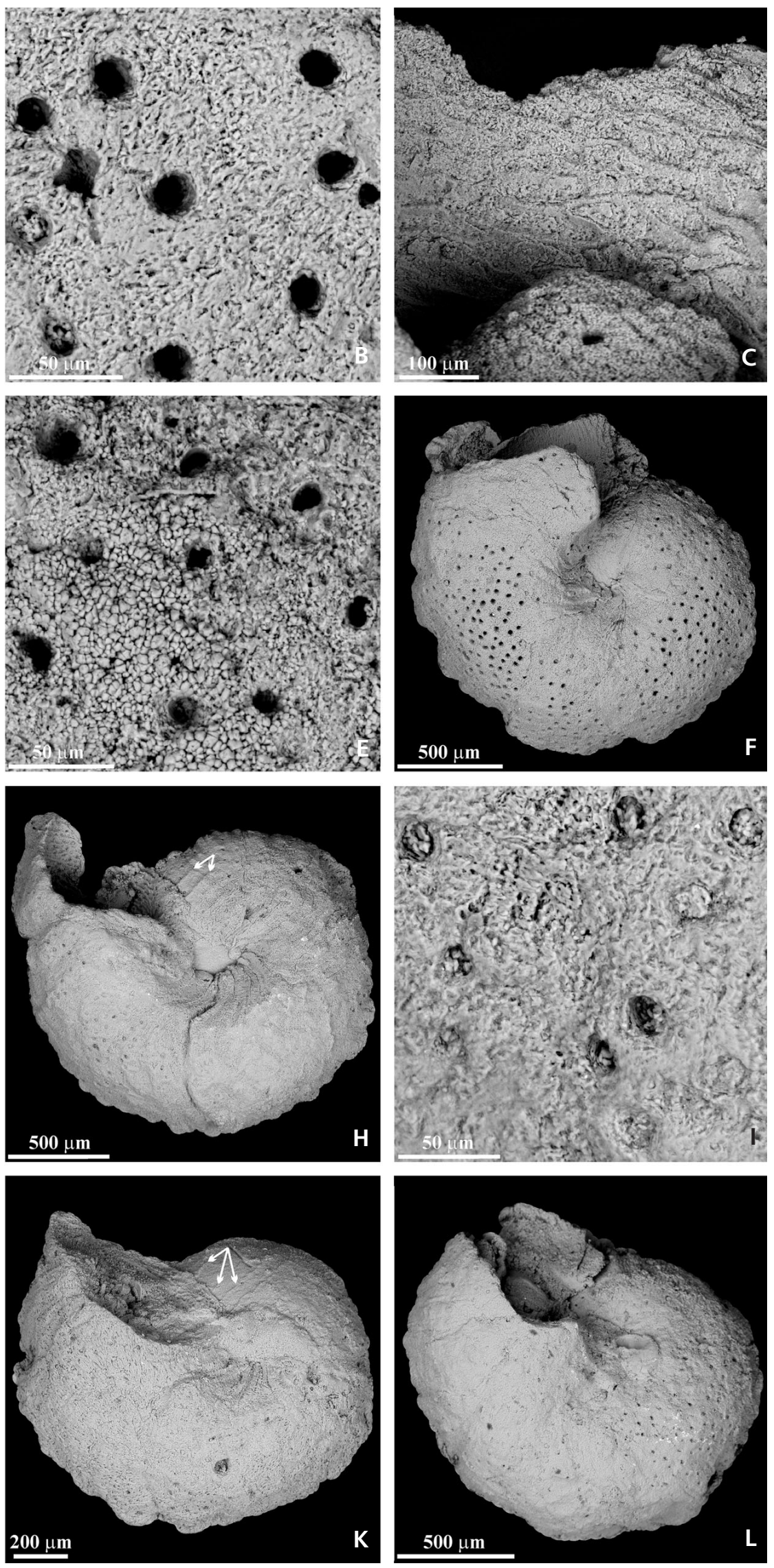
also apparent from the occurrence of encrusters between laminae of the oncolith crusts, as best seen in cross-sections. During stable intervals, most of the sclerobionts colonised the hidden lower sides of the oncoliths and their recesses. Overturning events were probably infrequent, as particular oncoliths have thin, discoidal shapes of low thickness and their surfaces are densely encrusted. Thus, a significant amount of time must have been available for colonisation before the next overturning event. The sedimentary environment of the host ore-bearing clays in the northerly sedimentary region is interpreted as calm and below storm wave-base (see Matyja et al. 2006a-c). That of the southern sedimentary region, where Ogrodzieniec is situated, was characterised by shallower, near-shore setting, with more frequent erosion and sedimentary hiatuses (see Różycki 1953). In such an environment, disturbance of the oncoliths leading to their overturning and recolonisation may have been caused by purely physical factors, such as storms or strong currents, or through biological action, e.g., bulldozing by burrowers, or browsing of the seabed by marine vertebrates.

The most abundant of all encrusters at Ogrodzieniec are serpulid worm tubes, forming dense aggregations on both lower and upper sides of the oncoliths, and bryozoans. Like 'scleroponges' and solitary scleractinian corals, microconchids are less abundant and are dominated by a single species, Punctaconchus ampliporus. In England and France the three microconchid species described by Vinn \& Taylor (2007) have not been observed to co-occur on the same substrates. The microconchids studied here were found on only ten oncoliths out of a sample size of forty complete oncoliths plus fragments. Moreover, on individual oncoliths, Punctaconchus occur as single or up to three individuals located close to each other, suggesting aggregative behaviour. Unlike serpulids, which are widely distributed over the oncoliths, microconchids (as well as thecideide brachiopods) occupied only crevices, recesses and lateral vertical sides of the oncoliths. They have not been observed fouling or being overgrown by other sclerobionts. The small number of microconchids may reflect their low competitive ability for substrate space and/or low recruitment rates during this time of progressive decline of the group towards its last known occurrence in the late Bathonian (Taylor \& Vinn 2006, Vinn \& Taylor 2007).

Although the encrusters under discussion, including microconchids, are characteristic components of many other hard substrates (see Taylor \& Wilson 2003 for a comprehensive review), in the Jurassic of Ogrodzieniec they occupied firm biogenic substrate probably produced by some kind of microbiota but sufficiently firm for attachment. Palaeozoic and Triassic microconchids are often reported from similar biosedimentary structures, including oncoliths and stromatolites (see Peryt 1974, Burchette \&
Riding 1977, Toomey \& Cys 1977, Dreesen \& Jux 1995, Wright \& Wright 1981, Mistiaen \& Poncet 1983). Palmer $\&$ Wilson (1990) found, among other diverse sclerobionts, microconchids (then under the name Spirorbula) encrusting Bajocian oncoliths ('snuff boxes') from England and France. Individuals of the microconchid Punctaconchus mildfordensis completely detached from their substrates were interpreted by Vinn \& Taylor (2007) to have colonized plants, soft-bodied organisms or aragonitic shells that dissolved.

The complete lack of microconchids encrusting other hard substrates, such as shells or hiatus concretions (see Zatoń et al. 2006, Zatoń \& Taylor 2009), in the Middle Jurassic ore-bearing clays of the Polish Jura, is striking. Possible explanations are that: (1) microconchids preferred shallow water environments whereas shells occurring within the host clays were deposited in deeper environments, below storm wave-base, and (2) the absence of microconchids on hiatus concretions bearing other diverse sclerobionts (albeit lacking thecideide brachiopods'), but of lower density than that occurring on the oncoliths studied, may be a taphonomic artefact. The small, delicate microconchid tubes may have been destroyed by abrasion as documented by many encrusters, as well as in truncated borings (Zatoń et al. 2006, Zatoń $\&$ Taylor 2009). Alternatively, it is possible that the hiatus concretions were never colonised by microconchids.

\section{Conclusions}

Tiny spirorbiform tubes assigned to the order Microconchida are described from the Middle Jurassic of Poland (Ogrodzieniec, Polish Jura) for the first time. The morphological and microstructural characteristics allow their identification as Punctaconchus, formerly described only from the Middle Jurassic (Aalenian-Upper Bathonian) of England and France. The smooth tube exterior pierced by large pores is characteristic of the species $P$. ampliporus, previously known only from southern England. The individuals of $P$. ampliporus have been found encrusting Lower Bathonian oncoliths from Ogrodzieniec. Their diversity is low and they are rare compared with associated encrusters such as serpulid tubes and bryozoans. This may reflect poor competitive ability for substrate space but also the generally low diversity and abundance of microconchids leading up to the final extinction of the group.

\section{Acknowledgements}

We thank Wojtek Krawczyński (University of Silesia, Poland) who helped in the field during collection of the microconchid- 
bearing oncoliths. Olev Vinn (University of Tartu, Estonia) is thanked for his comments on the microconchids. The journal referees, Olev Vinn (University of Tartu, Estonia) and Mark A. Wilson (College of Wooster, Ohio) are thanked for their useful remarks and comments.

\section{References}

BARSKI, M., DEMBICZ, K. \& PRASZKIER, T. 2004. Biostratygrafia i paleośrodowisko środkowej jury z kamieniołomu Ogrodzieniec. Tomy Jurajskie 2, 61-68.

BURCHETTE, T.P. \& RIDING, R. 1977. Attached vermiform gastropods in Carboniferous marginal marine stromatolites and biostromes. Lethaia 10, 17-28. DOI 10.1111/j.1502-3931.1977.tb00586.x

DADLEZ, R. 1989. Epikontynentalne baseny permu i mezozoiku w Polsce. Kwartalnik Geologiczny 33, 175-198.

DAYCZAK-CALIKOWSKA, K., KOPIK, J. \& MARCINKIEWICZ, T. 1997. Middle Jurassic, 236-282. In MAREK, S. \& PAJCHLOWA, M. (eds) Epikontynentalny perm i mezozoik $w$ Polsce. Prace Państwowego Instytutu Geologicznego 153.

DREESEN, R. \& JUX, U. 1995. Microconchid buildups from Late Famennian peritidal-lagoonal settings (Evieux Formation, Ourthe Valley, Belgium). Neues Jahrbuch für Geologie und Paläontologie, Abhandlungen 198, 107-121.

KOPIK, J. 1998. Jura dolna i środkowa północno-wschodniego obrzeżenia Górnosląskiego Zagłębia Węglowego. Biuletyn Państwowego Instytutu Geologicznego 378, 67-120.

MAJEWSKI, W. 2000. Middle Jurassic concretions from Częstochowa (Poland) as indicators of sedimentation rates. Acta Geologica Polonica 50, 431-439.

MARYNOWSKI, L., ZATOŃ, M., SimoneIT, B.R.T., OTTO, A., JĘDRYSEK, M.-O., GRELOWSKI, C. \& KURKIEWICZ, S. 2007. Compositions, sources and depositional environments of organic matter from the Middle Jurassic clays of Poland. Applied Geochemistry 22, 2456-2485.

DOI 10.1016/j.apgeochem.2007.06.015

MATYJA, B.A. \& WIERZBOWSKI, A. 1998. Palaeogeographic evolution of the Middle-Upper Jurassic of Poland, 161-179. In Poulsen, N.E., BoJESEN-KoEfoed, J., DREWNiAK, A., GŁowniak, E., Ineson, J., Matyja, B.A., Merta, T. \& WIERZBOWski, A. (eds) Mellem-Øvre Jura $i$ Polen. EEP-1995 projekt: Det polske Mellem-Øvre Epikratoniske Bassin, Stratigrafi, Facies og Bassin Historie. Program Østeuropa. Danmarks og Grønlands Geologiske Undersøgelse Rapport 1998/14.

MATYJA, B.A. \& WIERZBOWSKI, A. 2000. Ammonites and stratigraphy of the uppermost Bajocian and Lower Bathonian between Częstochowa and Wieluń, Central Poland. Acta Geologica Polonica 50, 191-209.

MATYJA, B.A. \& WIERZBOWSKI, A. 2006. European Platform Middle and Upper Jurassic, 130-132. In WIERZBOWSKI, A., Aubrecht, R., GolonKA, J., Gutowski, J., Krobicki, M., MATYJA, B.A., PIEŃKOWSKI, G. \& UCHMAN, A. (eds) Jurassic of Poland and adjacent Slovakian Carpathians. Field trip guidebook of $7^{\text {th }}$ International Congress on the Jurassic System Poland, Kraków, September 6-18, 2006.
Matyja, B.A., Wierzbowski, A., Gedl, P., Boczarowski, A., KAIM, A., KęDZIERSKI, M., LeONOWICZ, P., SMOleŃ, J., SZCZEPANIK, P. \& WITKOWSKA, M. 2006a. Stop B1.5 Sowa's and Glinski's clay pits (uppermost Bajocian-lowermost Bathonian), 149-152. In WIERZBOwsKI, A., AUBRECht, R., GolonkA, J., Gutowski, J., Krobicki, M., MATYJA, B.A., PIEŃKOwski, G. \& UCHMAN, A. (eds) Jurassic of Poland and adjacent Slovakian Carpathians. Field trip guidebook of $7^{\text {th }}$ International Congress on the Jurassic System Poland, Kraków, September 6-18, 2006.

Matyja, B.A., Wierzbowski, A., GedL, P., Boczarowski, A., KęDZIERSKi, M., LeONOWiCZ, P., SMOLEŃ, J., SZCZEPANIK, P. \& WiTKOWSKA, M. 2006b. Stop B1.6 - Leszczyński's clay pit (Lower Bathonian), 152-154. In WIERZBOWSKI, A., AUBREChT, R., GOLONKA, J., GUTOWSKI, J., Krobicki, M., Matyja, B.A., Pieńkowski, G. \& UCHMAN, A. (eds) Jurassic of Poland and adjacent Slovakian Carpathians. Field trip guidebook of $7^{\text {th }}$ International Congress on the Jurassic System Poland, Kraków, September 6-18, 2006.

Matyja, B.A., Wierzbowski, A., GedL, P., BocZARowski, A., DudeK, T., KAIM, A., KęDZIERSKI, M., LeONOWiCZ, P., SMOleń, J., SZCZEPANiK, P., WitKowska, M., ZiajA, J., BARSKI, M. \& OSTROWSKI, S. 2006c. Stop B1.7 - Gnaszyn clay pit (Middle Bathonian-lowermost Upper Bathonian), 154-157. In WiERZBOWski, A., AUBreCHT, R., GOLONKA, J., Gutowski, J., Krobicki, M., Matyja, B.A., PieŃKOWSKI, G. \& UCHMAN, A. (eds) Jurassic of Poland and adjacent Slovakian Carpathians. Field trip guidebook of $7^{\text {th }}$ International Congress on the Jurassic System Poland, Kraków, September 6-18, 2006.

Mistiaen, B. \& PONCET, J. 1983. Stromatolithes, Serpulidés et Trypanopora (Vers?), associés dans de petits biohermes Givétiens du Boulonnais. Palaeogeography, Palaeoclimatology, Palaeoecology 41, 125-138. DOI 10.1016/0031-0182(83)90080-9

PALMER, T.J. \& FÜRSICH, F.T. 1974. The ecology of a Middle Jurassic hardground and crevice fauna. Palaeontology 17 , 507-524.

PALMER, T.J. \& WiLSON, M.A. 1990. Growth of ferrugineous oncoliths in the Bajocian (Middle Jurassic) of Europe. Terra Nova 2, 142-147. DOI 10.1111/j.1365-3121.1990.tb00055.x

PERYT, T.M. 1974. Spirorbid-algal stromatolites. Nature 249, 239-240. DOI 10.1038/249239a0

POULSEN, N.S. 1998. Upper Bajocian to Callovian (Jurassic) dinoflagellate cysts from central Poland. Acta Geologica Polonica 48, 237-245.

RÓŻYCKI, S.Z. 1953. Górny dogger i dolny malm Jury Krakowsko-Częstochowskiej. Prace Instytutu Geologicznego 17, $1-420$.

TAYLOR, P.D. 2009. Bryozoans from the Middle Jurassic of Balin, Poland: a revision of material described by A.E. Reuss (1867). Annalen-Naturhistorisches Museum Vien 110A, $17-54$.

TAYLOR, P.D. \& VINN, O. 2006. Convergent morphology in small spiral worm tubes ('Spirorbis') and its palaeoenvironmental implications. Journal of the Geological Society, London 163, 225-228. DOI 10.1144/0016-764905-145

TAYLOR, P.D. \& WILSON, M.A. 2003. Palaeoecology and evolu- 
tion of marine hard substrate communities. Earth-Science Reviews 62, 1-103. DOI 10.1016/S0012-8252(02)00131-9

TOOMEY, D.F. \& CYS, J.M. 1977. Spirorbid/algal stromatolites, a probable marginal marine occurrence from the Lower Permian of New Mexico, USA. Neues Jahrbuch für Geologie und Paläontologie, Monatshefte 6, 331-342.

VINN, O. 2006. Two new microconchid (Tentaculita Bouček, 1964) genera from the Early Palaeozoic of Baltoscandia and England. Neues Jahrbuch für Geologie und Paläontologie, Monatshefte 2, 89-100.

VINN, O. \& TAYLOR, P.D. 2007. Microconchid tubeworms from the Jurassic of England and France. Acta Palaeontologica Polonica 52, 391-399.

WEEDON, M.J. 1991. Microstructure and affinity of the enigmatic Devonian tubular fossil Trypanopora. Lethaia 24, 227-234. DO1 10.1111/j.1502-3931.1991.tb01471.x

WEEDON, M.J. 1994. Tube microstructure of Recent and Jurassic serpulid polychaetes and the question of the Palaeozoic 'spirorbids'. Acta Palaeontologica Polonica 39, 1-15.

WILSON, M.A. 1986. Coelobites and spatial refuges in a Lower
Cretaceous cobble-dwelling hardground fauna. Palaeontology 29, 691-703.

WRIGHT, V.P. \& WRIGHT, E.V.G. 1981. The palaeoecology of some algal-gastropod bioherms in the Lower Carboniferous of South Wales. Neues Jahrbuch für Geologie und Paläontologie, Monatschefte 9, 546-558.

ZATOŃ, M., MARYNOWSKI, L. \& BZOWSKA, G. 2006. Konkrecje hiatusowe z iłów rudonośnych Wyżyny Krakowsko-Częstochowskiej. Przegląd Geologiczny 54, 131-138.

ZAtoń, M. \& TAYLOR, P.D. 2009. Middle Jurassic cyclostome bryozoans from the Polish Jura. Acta Palaeontologica Polonica 54, 267-288. DO1 10.4202/app.2008.0088

ZATOŃ, M., MARYNOWSKI, L., SZCZEPANIK, P., BOND, D.P.G. \& Wignall, P.B. 2009. Redox conditions during sedimentation of the Middle Jurassic (Upper Bajocian-Bathonian) clays of the Polish Jura (south-central Poland). Facies 55, 103-114. DOI 10.1007/s10347-008-0159-Z

ZIEGLER, P.A. 1990. Geological atlas of western and central Europe. 239 pp. Shell Internationale Petroleum Maatschappij B.V., London. 